\title{
Main trends and scale of changes in state of energy security of the regions of Russia
}

\author{
Elena Smirnova ${ }^{1, *}$, Sergey Senderov ${ }^{1}$ \\ ${ }^{1}$ Melentiev Energy Systems Institute, 130 Lermontov str., Irkutsk, Russia
}

\begin{abstract}
The paper is devoted to the analysis of the main trends and the scale of the change in the state of energy security of Russian regions. The analysis of the problems was carried out in accordance with the methodology for assessing the state of energy security of the Russian Federation at the regional level. The regions of Russia with unsatisfactory state of energy security, as well as the dynamics of changes in the state of energy security in all regions of Russia in the period from 2011 to 2016 are determined. The factors and reasons for the formation of negative and positive trends are analysed.
\end{abstract}

\section{Introduction}

Energy security (ES) - the state of protection of citizens, society, the state, the economy from the threat of a deficit in providing their energy needs with economically accessible energy resources of acceptable quality, from threats of disrupting the continuity of energy supply [1, 2]. In fact, energy security is the balance of energy supply and demand or the lack of deficit of energy balance.

To assess the state of the ES regions of Russia and, to identify emerging trends in this regard, appropriate monitoring and analysis of the state of domestic energy is needed. Such an assessment should be carried out in accordance with the methodology for monitoring the state of Russia's ES at the regional level, that is, on the basis of monitoring the most important indicators of the functioning of energy at a given point in time.

This paper presents materials that characterize the state of ES in the regions of Russia across all federal districts. Such estimates were obtained with the direct use of the monitoring technique for the state of ES [3], provided with the necessary illustrative material. Individual regions are ranked according to the state of their ES. Studies conducted in different time frames (2011, 2015 and 2016), allow us to assess the direction of the change in the situation with the provision of ES in the regions of Russia and the dynamics of these changes over the past six years.

In all developed countries, the issues and problems of ensuring an acceptable level of energy security are receiving increasing attention. For example, in [1] the situation with ES indicators and the situation in Europe as a whole is reflected. In $[5,6]$ the same information is presented about Turkey and the countries of Asia. In general, the literature on the assessment of energy security focuses on the problems of diversification of energy supply sources, diversification of suppliers of imported energy. The issues of long-term political stability in the regions under consideration and issues of improving the situation with the provision of ES by regions of the world are touched upon. For the purpose of carrying out the corresponding analysis, specialists develop and use various indicators and systems of indicative analysis, adapted for a particular region [2-4]. At the same time in Russia, there is a system of indicators that allows us to assess the situation with energy security in the approach to the realities of modern Russia and its specifics. This takes into account the peculiarities of each region. In general, the system of indicative analysis used provides concrete benchmarks aimed at improving the situation in individual regions and in the country as a whole. This paper is devoted to the description of the regional aspect of this problem.

\section{Elements of the methodology for monitoring the state of Russia's ES at the regional level}

Currently, the evaluation of the state of the ES regions of the country $[3,10]$ is based on the use of indicators distributed across three interrelated blocks, Table. 1 . The values of indicators characterize the conditions for securing ES in the region in aggregate. Separation of individual blocks is necessary to obtain an idea of the most important aspects of securing the ES regions. Each of the presented in Table 1 indicator has its own, expertly generated and justified, threshold values, that is, those values that determine the boundary of the transition of the actual value of the indicator from one area of qualitative states to another. 
The methodology uses two such thresholds for each indicator. The pre-crisis threshold value of the indicator means the boundary value between the normal and precrisis state of energy in the aspect described by this indicator. The crisis threshold means, respectively, the boundary between the pre-crisis and crisis states.

As a result of comparing the actual values of specific indicators with their thresholds, the level of crisis indicators is estimated. But in this case it is not yet possible to judge the crisis of the state of the region's ES in general. Some indicators can have acceptable from the EB positions, the values of others may be in crisis or precrisis conditions. The picture can vary from region to region and from year to year. Accordingly, in order to form a final qualitative assessment of the state of ES in the region, it is necessary to convolve qualitative assessments of the status of individual indicators in a single integrated assessment of the ES of the analysed territory.

Table 1. Composition of the most important indicators of regional energy security.

\section{Block of production and resource provision of the region's} fuel and energy supply system

1.1. The ratio of the total available capacity of the region's power plants to the maximum electric load of consumers on its territory.

1.2. The ratio of the amount of available capacity of power plants and the throughput of interconnections between the region and neighboring consumers to the maximum electric load on its territory.

1.3. Opportunities to meet the needs of Boiler Heating Oil (BHO) from the region's own sources.

2. The block of reliability of fuel and energy supply of the region

2.1. The share of the dominant resource in the total consumption of $\mathrm{BHO}$ in the territory of the region.

2.2. The share of the largest power plant in the installed electric capacity of the region.

2.3. The level of potential supply of demand for fuel in the conditions of a sharp cooling ( $10 \%$ consumption of consumption) in the region.

3. Block of the state of Basic Production Assets (BPA) energy systems in the territory of the region

3. Block of the state of BPA energy systems in the territory of the region

3.1. Degree of depreciation of the BPA in the energy sector of the region.

3.2. The ratio of the average annual input of installed capacity and reconstruction of power plants in the region over the last 5year period to the established capacity of the region.

The state of a particular indicator, depending on the location of its values on the state scale, is estimated as follows:

$$
f\left(S_{i}\right)=\left\{\begin{array}{l}
\mathrm{N}, S_{i}<S_{i}^{P C} \\
P C, S_{i}^{P C} \leq S_{i}<S_{i}^{C} \quad i=1, n \\
C, S_{i} \geq S_{i}^{C}
\end{array}\right.
$$

where $n-$ is the number of indicators being evaluated; $S i$ - actual (expected) value of the i-th indicator; $S_{i}^{P C}, S_{i}^{C}$ - the pre-crisis and crisis threshold values of the $i$-th indicator; $N, P C, C$ - qualitative assessment of the state of energy in the aspect indicated by the $i$-th indicator: normal, pre-crisis and crisis, respectively.

Due to the fact that the indicators chosen for the assessment are not of equal importance in their importance, an integral evaluation takes into account the significance of each specific indicator in their common set. Or the "weights" of specific indicators in the overall system of their values. The specific weight of the indicator in the total sum of weights is determined by the formula:

$$
V_{i}=\sum_{j=1}^{n} v_{i j} / \sum_{i=1}^{n} \sum_{j=1}^{n} v_{i j}
$$

where $V_{i}$ - is the specific weight of the $i$-th indicator in the system of indicators being evaluated; $V_{i j}$ conditional significance of the $i$-th indicator in comparison with the $j$-th indicator.

When carrying out the above-described procedure for actions, a qualitative assessment of the state of individual regions of Russia is formed:

$$
Q=\left\{\begin{array}{l}
\mathrm{N}, \sum_{i=1}^{n} V_{i}^{\mathrm{N}} \geq \delta_{N} \\
P C, \sum_{i=1}^{n} V_{i}^{C} \prec \delta_{C} \text { and } \sum_{i=1}^{n} V_{i}^{N} \prec \delta_{N}, i=1, n \\
C, \sum_{i=1}^{n} V_{i}^{C} \geq \delta_{C}
\end{array}\right.
$$

where $Q$ - an integral assessment of the qualitative state of the region's energy security; $V_{i}^{N}, V_{i}^{C}$ - the specific weight of the $i$-th indicator, located in the area of normal and crisis values, respectively; $\delta_{N}, \delta_{C}$ - coefficients that characterize the level of achievement of a normal or a crisis state, respectively. Carrying out such an assessment allows on the basis of monitoring the dynamic range of the integral indicator values, to understand in which direction the level of ES in a particular region is changing and which region should, first of all, pay attention to the level of the federal district or country.

\section{Analysis of the state of the ES regions of Russia}

In order to demonstrate the efficiency of the methodological approach discussed above, to highlight and assess some trends in the changing of the most important factors for ensuring the safety of subjects located on the territory of the Russian Federation, the following was done. The subjects of the Russian 
Federation for analysis are located in the territories of all federal districts. According to these districts, an information base has been created, based on statistical information [11-13]. In the dynamics from 2011 to 2016. Values of all indicators listed above are estimated. At the same time, the values of the indicators were quantitatively correlated with their threshold values, and all regions were allocated to the respective groups of territories. With the help of this, it became possible to assess the qualitative state of each indicator in the relevant subject of analysis. As a result of the general analysis of data on 78 subjects of the Russian Federation, it is possible to characterize briefly the energy inherent in the territories of the federal districts, from the standpoint of energy security requirements.

Based on the results of the analysis conducted in the dynamics from 2011 to 2016 . The share of regions where the situation from the ES's point of view has not fundamentally changed is $82 \%$. Information on the state of these regions and their location in the area of a crisis, normal or border pre-crisis state is shown in the graph (Fig. 1).

In general, the unsatisfactory situation of ensuring the ES for the constituent entities of the Russian Federation is shown on the graph (Fig. 1), shows that most of the regions are located in the area of crisis and pre-crisis values of the indicator weights.

Let's dwell on regions where the situation with providing ES has changed qualitatively, these regions are presented in Table 2.

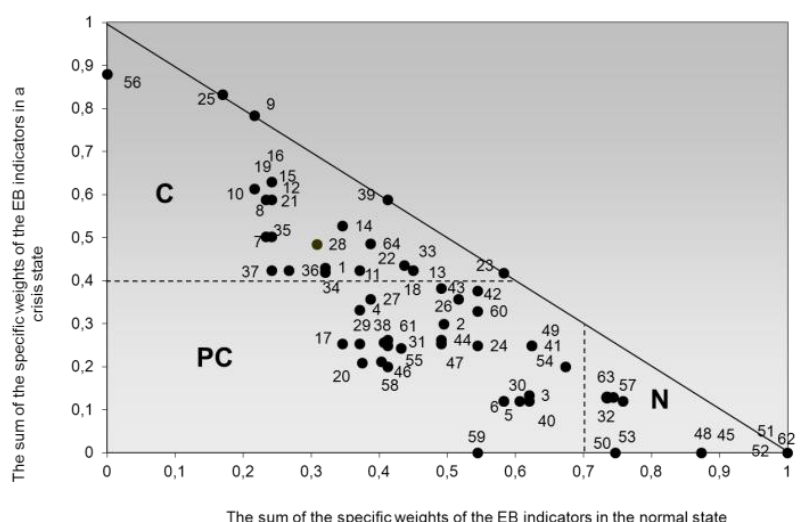

Fig. 1. The final state of the ES of the subjects of the Russian Federation, 2016

1 - The Republic of Karelia; 2 - the Republic of Komi; 3 - the Vologda region; 4 - the Kaliningrad region; 5 - the Leningrad Region; 6 - Murmansk region; 7 - Novgorod Region; 8 - Pskov Region; 9 - Belgorod Region; 10 Bryansk region; 11 - Vladimir Region; 12 - Voronezh Region; 13 - Ivanovo Region; 14 - the Kaluga area; 15 Kostroma Region; 16 - Kursk Region; 17 - Lipetsk Region; 18 - Moscow region; 19 - Orel region; 20 Ryazan Region; 21 - Smolensk region; 22 - Tver Region; 23 - Yaroslavl Region; 24 - The Republic of Dagestan; 25 - Kabardino-Balkaria Republic; 26 - Republic of North Ossetia-Alania; 28 - the Chechen Republic; 29 Stavropol Territory; 30 - Krasnodar Territory; 31 Volgograd Region; 32 - Rostov Region; 33 - Republic of Kalmykia; 34 - Republic of Bashkortostan; 35 - Republic of Mordovia; 36 - The Republic of Udmurtia; 37 Chuvash Republic; 38 - the Orenburg region; 39 - Penza region; 40 - Perm Territory; 41 - Samara Region; 42 Saratov Region; 43 - Ulyanovsk Region; 44 - Sverdlovsk Region; 45 - Tyumen region; 46 - Chelyabinsk Region; 47 - Altai Territory; 48 - Kemerovo Region; 49 Novosibirsk Region; 50 - Omsk Region; 51 - Tomsk Region; 52 - Krasnoyarsk Territory; 53-Irkutsk Region; 54 - Republic of Buryatia; 55 - The Republic of Tuva; 56 - The Altai Republic; 57 - the Republic of Sakha (Yakutia); 58 - Primorsky Territory; 59 - Khabarovsk Territory; 60 - the Amur Region; 61 - Kamchatka Territory; 62 - Sakhalin Oblast; 63 - Chukotka Autonomous District; 64 - Jewish Autonomous Region. 
Table 2. Assessment of the qualitative state of certain regions of the Russian Federation

\begin{tabular}{|c|c|c|c|c|c|c|c|c|c|c|c|c|}
\hline \multirow{4}{*}{$\stackrel{\vec{d}}{\grave{d}}$} & \multicolumn{8}{|c|}{ The order numbers of the estimated ES indicators * } & \multirow{2}{*}{\multicolumn{3}{|c|}{$\begin{array}{l}\text { The sum of the specific weights by } \\
\text { state } \\
\text { Boundaries of states }\end{array}$}} & \multirow{4}{*}{ 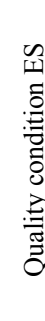 } \\
\hline & $\exists$ & $\stackrel{\text { Iִ }}{-}$ & $\dddot{m}$ & $\vec{i}$ & $\stackrel{\sim}{\sim}$ & $\stackrel{m}{i}$ & $\vec{m}$ & $\stackrel{\sim}{n}$ & & & & \\
\hline & \multicolumn{8}{|c|}{ Specific weights of indicators } & \multirow[b]{2}{*}{$\mathrm{C}^{\mathrm{a}}$} & \multirow[b]{2}{*}{$\mathrm{PC}$} & \multirow[b]{2}{*}{$\mathrm{N}^{\mathrm{b}}$} & \\
\hline & $\begin{array}{l}t \\
\stackrel{0}{0}\end{array}$ & $\begin{array}{l}\infty \\
\stackrel{\infty}{0} \\
0\end{array}$ & $\begin{array}{l}m \\
0 \\
0\end{array}$ & $\begin{array}{l}\stackrel{0}{0} \\
0\end{array}$ & 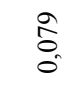 & $\stackrel{?}{\stackrel{2}{0}}$ & $\begin{array}{l}\hat{\jmath} \\
\hat{0}\end{array}$ & $\frac{\text { సे }}{0}$ & & & & \\
\hline 1 & 2 & 3 & 4 & 5 & 6 & 7 & 8 & 9 & 10 & 11 & 12 & 13 \\
\hline \multicolumn{13}{|c|}{ Archangelsk region } \\
\hline 2011 & $\mathrm{~N}$ & $\mathrm{~N}$ & $\mathrm{C}$ & $\mathrm{PC}$ & $\mathrm{N}$ & $\mathrm{C}$ & $\mathrm{PC}$ & $\mathrm{N}$ & 0,303 & 0,247 & 0,450 & PC \\
\hline 2016 & $\mathrm{~N}$ & $\mathrm{~N}$ & $\mathrm{C}$ & $\mathrm{PC}$ & $\mathrm{N}$ & $\mathrm{C}$ & $\mathrm{N}$ & $\mathrm{C}$ & 0,432 & 0,120 & 0,448 & C \\
\hline \multicolumn{13}{|c|}{ Tambov Region } \\
\hline 2011 & $\mathrm{~N}$ & $\mathrm{~N}$ & $\mathrm{C}$ & $\mathrm{C}$ & PC K & $\mathrm{PC}$ & $\mathrm{C}$ & $\mathrm{PC}$ & 0,380 & 0,378 & 0,242 & PC \\
\hline 2016 & $\mathrm{~N}$ & $\mathrm{~N}$ & $\mathrm{C}$ & $\mathrm{C}$ & $\mathrm{PC}$ & $\mathrm{PC}$ & $\mathrm{C}$ & $\mathrm{C}$ & 0,509 & 0,249 & 0,242 & $\mathbf{C}$ \\
\hline \multicolumn{13}{|c|}{ Tula region } \\
\hline 2011 & $\mathrm{~N}$ & $\mathrm{~N}$ & $\mathrm{C}$ & $\mathrm{C}$ & $\mathrm{PC}$ & $\mathrm{PC}$ & $\mathrm{C}$ & $\mathrm{C}$ & 0,509 & 0,249 & 0,242 & $\mathbf{C}$ \\
\hline 2016 & $\mathrm{~N}$ & $\mathrm{~N}$ & $\mathrm{C}$ & $\mathrm{C}$ & $\mathrm{N}$ & $\mathrm{PC}$ & $\mathrm{PC}$ & $\mathrm{N}$ & 0,253 & 0,297 & 0,450 & PC \\
\hline \multicolumn{13}{|c|}{ Karachay-Cherkess Republic } \\
\hline 2011 & $\mathrm{~N}$ & $\mathrm{~N}$ & $\mathrm{C}$ & $\mathrm{C}$ & $\mathrm{N}$ & $\mathrm{N}$ & $\mathrm{N}$ & $\mathrm{N}$ & 0,253 & 0 & 0,747 & $\mathbf{N}$ \\
\hline 2016 & $\mathrm{~N}$ & $\mathrm{~N}$ & $\mathrm{C}$ & $\mathrm{C}$ & $\mathrm{N}$ & $\mathrm{N}$ & $\mathrm{N}$ & $\mathrm{PC}$ & 0,253 & 0,129 & 0,618 & PC \\
\hline \multicolumn{13}{|c|}{ Astrakhan region } \\
\hline 2011 & $\mathrm{~N}$ & $\mathrm{~N}$ & $\mathrm{~N}$ & $\mathrm{~N}$ & $\mathrm{PC}$ & $\mathrm{N}$ & $\mathrm{PC}$ & $\mathrm{C}$ & 0,129 & 0,206 & 0,665 & PC \\
\hline 2016 & $\mathrm{~N}$ & $\mathrm{~N}$ & $\mathrm{~N}$ & $\mathrm{~N}$ & $\mathrm{PC}$ & $\mathrm{N}$ & $\mathrm{PC}$ & $\mathrm{N}$ & 0 & 0,206 & 0,794 & $\mathbf{N}$ \\
\hline \multicolumn{13}{|c|}{ Mari EI Republic } \\
\hline 2011 & $\mathrm{~N}$ & $\mathrm{~N}$ & $\mathrm{PC}$ & $\mathrm{C}$ & $\mathrm{N}$ & $\mathrm{C}$ & $\mathrm{PC}$ & $\mathrm{C}$ & 0,419 & 0,26 & 0,321 & $\mathrm{C}$ \\
\hline 2016 & $\mathrm{~N}$ & $\mathrm{~N}$ & $\mathrm{~N}$ & $\mathrm{C}$ & $\mathrm{N}$ & $\mathrm{C}$ & $\mathrm{PC}$ & $\mathrm{N}$ & 0,29 & 0,127 & 0,583 & PC \\
\hline \multicolumn{13}{|c|}{ Republic of Tatarstan } \\
\hline 2011 & $\mathrm{~N}$ & $\mathrm{~N}$ & $\mathrm{PC}$ & $\mathrm{C}$ & $\mathrm{N}$ & $\mathrm{C}$ & $\mathrm{PC}$ & $\mathrm{C}$ & 0,419 & 0,26 & 0,321 & $\mathbf{C}$ \\
\hline 2016 & $\mathrm{~N}$ & $\mathrm{~N}$ & $\mathrm{~N}$ & $\mathrm{C}$ & $\mathrm{N}$ & $\mathrm{C}$ & $\mathrm{PC}$ & $\mathrm{PC}$ & 0,29 & 0,256 & 0,454 & PC \\
\hline \multicolumn{13}{|c|}{ Kirov region } \\
\hline 2011 & $\mathrm{~N}$ & $\mathrm{~N}$ & $\mathrm{C}$ & $\mathrm{C}$ & $\mathrm{N}$ & $\mathrm{N}$ & $\mathrm{C}$ & $\mathrm{C}$ & 0,509 & 0 & 0,491 & $\mathbf{C}$ \\
\hline 2016 & $\mathrm{~N}$ & $\mathrm{~N}$ & $\mathrm{C}$ & $\mathrm{C}$ & $\mathrm{N}$ & $\mathrm{N}$ & $\mathrm{C}$ & $\mathrm{N}$ & 0,38 & 0 & 0,62 & PC \\
\hline \multicolumn{13}{|c|}{ Nizhny Novgorod Region } \\
\hline 2011 & $\mathrm{~N}$ & $\mathrm{~N}$ & $\mathrm{~N}$ & $\mathrm{C}$ & $\mathrm{N}$ & $\mathrm{N}$ & $\mathrm{PC}$ & $\mathrm{C}$ & 0,249 & 0,127 & 0,624 & PC \\
\hline 2016 & $\mathrm{~N}$ & $\mathrm{~N}$ & $\mathrm{~N}$ & $\mathrm{C}$ & $\mathrm{N}$ & $\mathrm{N}$ & $\mathrm{PC}$ & $\mathrm{N}$ & 0,12 & 0 & 0,88 & $\mathbf{N}$ \\
\hline \multicolumn{13}{|c|}{ Kurgan region } \\
\hline 2011 & $\mathrm{~N}$ & $\mathrm{~N}$ & $\mathrm{C}$ & $\mathrm{C}$ & $\mathrm{C}$ & $\mathrm{N}$ & $\mathrm{C}$ & $\mathrm{C}$ & 0,588 & 0 & 0,412 & $\mathbf{C}$ \\
\hline 2016 & $\mathrm{~N}$ & $\mathrm{~N}$ & $\mathrm{C}$ & $\mathrm{C}$ & $\mathrm{PC}$ & $\mathrm{N}$ & $\mathrm{PC}$ & $\mathrm{N}$ & 0,253 & 0,206 & 0,541 & PC \\
\hline \multicolumn{13}{|c|}{ The Republic of Khakassia } \\
\hline 2011 & $\mathrm{~N}$ & $\mathrm{~N}$ & $\mathrm{~N}$ & $\mathrm{PC}$ & $\mathrm{C}$ & $\mathrm{N}$ & $\mathrm{PC}$ & $\mathrm{N}$ & 0,079 & 0,247 & 0,674 & PC \\
\hline 2016 & $\mathrm{~N}$ & $\mathrm{~N}$ & $\mathrm{~N}$ & $\mathrm{PC}$ & $\mathrm{C}$ & $\mathrm{N}$ & $\mathrm{N}$ & $\mathrm{N}$ & 0,079 & 0,12 & 0,801 & $\mathbf{N}$ \\
\hline & & & & & & nsbail & gion & & & & & \\
\hline 2011 & $\mathrm{PC}$ & $\mathrm{PC}$ & $\mathrm{N}$ & $\mathrm{PC}$ & $\mathrm{PC}$ & $\mathrm{N}$ & $\mathrm{PC}$ & $\mathrm{C}$ & 0,129 & 0,568 & 0,303 & PC \\
\hline 2016 & $\mathrm{~N}$ & $\mathrm{~N}$ & $\mathrm{~N}$ & $\mathrm{PC}$ & $\mathrm{N}$ & $\mathrm{N}$ & $\mathrm{PC}$ & $\mathrm{N}$ & 0 & 0,247 & 0,753 & $\mathbf{N}$ \\
\hline & & & & & & gadaI & & & & & & \\
\hline 2011 & $\mathrm{~N}$ & $\mathrm{~N}$ & $\mathrm{C}$ & $\mathrm{C}$ & $\mathrm{C}$ & $\mathrm{N}$ & $\mathrm{PC}$ & $\mathrm{C}$ & 0,461 & 0,127 & 0,412 & C \\
\hline 2016 & $\mathrm{~N}$ & $\mathrm{~N}$ & $\mathrm{PC}$ & $\mathrm{C}$ & $\mathrm{C}$ & $\mathrm{N}$ & $\mathrm{PC}$ & $\mathrm{C}$ & 0,328 & 0,26 & 0,412 & PC \\
\hline & & & & & & ublic & mea & & & & & \\
\hline 2011 & $\mathrm{C}$ & $\mathrm{N}$ & $\mathrm{C}$ & $\mathrm{C}$ & $\mathrm{N}$ & $\mathrm{N}$ & $\mathrm{PC}$ & $\mathrm{C}$ & 0,486 & 0,127 & 0,387 & $\mathrm{C}$ \\
\hline 2016 & $\mathrm{C}$ & $\mathrm{N}$ & $\mathrm{C}$ & $\mathrm{C}$ & $\mathrm{N}$ & $\mathrm{N}$ & $\mathrm{PC}$ & $\mathrm{N}$ & 0,357 & 0,127 & 0,516 & PC \\
\hline
\end{tabular}

${ }^{a}$ The state of ES in the region is recognized as a crisis if the sum of the specific weights of the indicators in the state "C" exceeds 0.4

${ }^{\mathrm{b}}$ The state of ES in the region is recognized as normal if the sum of the specific weights of the indicators in the state "N" exceeds 0.7 
In 2016, the crisis situation was noted in all regions of the Central Federal District, with the exception of the Lipetsk, Ryazan and Tula oblasts. In the Tula region (Table 2), the crisis situation shifted to the pre-crisis one due to commissioning of capacities in 2013-2015. (At Novomoskovskaya GRES 190 MW and the start-up of two hydroelectric generators at Cherepetskaya GRES with a capacity of $225 \mathrm{MW}$ each).

For the analysed six-year period, the situation improved in such regions as the Republic of Mari El, the Republic of Tatarstan, Kirov, Kurgan, Magadan oblasts and the Republic of Crimea (Table 2). Improvement of the situation was due to the active policy of renewal of BPA the conduct of planned capital repairs in electricity and heat and power and made it possible to bring the situation in the regions into the region of pre-crisis values from the crisis. For example, in the Republic of Tatarstan, 590 MW of new generating capacities were commissioned in the last three years of the analysed period (2014-2016). Gas production in the republic increased almost threefold, which increased the ability to meet the needs of the BHO from the region's own sources and switched to the range of normal values by the corresponding indicator (1.3) (Table 2).

In the Republic of Crimea, the situation is improving every year, through the implementation of projects for the construction of generation facilities on the territory of the republic and the provision of reliable and uninterrupted power supply. The region has considerable potential for the development of alternative energy sources, such as solar and wind. In 2014, a wind farm with a capacity of $25 \mathrm{MW}$ was commissioned, and in 2015-2016, Commissioned four lines of energy bridge to connect the grid of the Crimea to the UPS of Russia (IPS South), with a total capacity of $800 \mathrm{MW}$. However, at the same time, wear of power equipment on the peninsula is about $70 \%$, which requires appropriate attention and taking measures to reduce it.

It is worth paying attention to those regions where the situation with ES has stabilized in six years, and by 2016 has moved into the region of acceptable values. There are only four such subjects $(5 \%$ of the total number of analysed): the Astrakhan Region, the Nizhny Novgorod Region, the Republic of Khakassia and the Trans-Baikal Territory. The conditions for improving the situation were: modernization of electric power equipment, the annual commissioning of new generating capacities and, as a consequence, a decrease in the share of a large source in the region's available electric power (index 2.2), as well as an increase in the ability to meet the needs for (BHO) from the region's own sources.

Table 3 presents an assessment of the state of the regions of the Russian Federation in terms of indicators for 2016.
Table 3. Assessment of the state of the ES regions of the Russian Federation by indicators for 2016, \%

\begin{tabular}{|c|l|l|l|l|l|l|l|l|}
\hline $\begin{array}{c}\text { Integral } \\
\text { assessme } \\
\text { nt of the } \\
\text { state of } \\
\text { ES by } \\
\text { regions }\end{array}$ & 1.1 & 1.2 & 1.3 & 2.1 & 2.2 & 2.3 & 3.1 & 3.2 \\
\hline $\mathrm{N}$ & 79 & 92 & 36 & 13 & 53 & 56 & 10 & 46 \\
\hline $\mathrm{C}$ & 17 & 4 & 55 & 69 & 27 & 27 & 20 & 41 \\
\hline $\mathrm{PC}$ & 4 & 4 & 9 & 18 & 20 & 17 & 70 & 13 \\
\hline
\end{tabular}

It can be seen from the table that in $69 \%$ of regions the crisis situation arises from the high share of the dominant resource in the total consumption of the region's BHO (indicator 2.1). These include all regions of the Central, North Caucasian, Volga Federal Districts, as well as the Kaliningrad, Leningrad, Murmansk, Novgorod and Pskov regions of the North-West Federal District, which do not have sufficient sources of their own for the production of $\mathrm{BHO}$, and the dominant type of fuel is the gas. As shown in Table 3, for indicator 1.3 (the ability to meet the needs of the BHO from the region's own sources) - the share of regions in crisis is $55 \%$.

\section{Conclusion}

Based on the results of the work done, the following conclusions can be drawn.

In general, the situation of providing ES by subjects of the Russian Federation is unsatisfactory. Most of the regions are located in the area of crisis and pre-crisis values of indicator weights.

It can be noted that a relatively high percentage of regions with an acceptable state from the EB's point of view on indicator 1.2 (The ratio of the sum of the available capacity of power plants and the capacity of interconnections of the region with neighbouring to the maximum electric load of consumers in its territory) is $92 \%$ and according to indicator 1.1 (The ratio of the total The available capacity of the region's power plants to the maximum electric load of consumers on its territory) $79 \%$ of the regions.

The pre-crisis situation in $70 \%$ of the regions, according to Table 3 , is affected by the unsatisfactory state of indicator 3.1 - the degree of depreciation of the basic production assets of the energy sector in the region. Since in most of the constituent entities of the Russian Federation the current values of the degree of wear and tear of equipment are $50-60 \%$. 


\section{References}

1. V.V. Bushuev, N.I. Voropay, A.M. Mastepanov, Yu.K. Shafranik Energy Security of Russia (Siberian Publishing Company RAS, Novosibirsk, 1998)

2. N.I. Pyatkova, S.M. Senderov, M.B. Cheltsov et al. Izvestiya RAN. Energetika, 6 (2000)

3. S.M. Senderov, N.I. Pyatkova, V.I. Rabchuk, G.B. Slavin, S.V. Vorobiev, E.M. Smirnova (ISEM SB RAS, Irkutsk, 2014)

4. Rocco C, Tarantola S, Costescu Badea A, Bolado Lavin R. ,ESREL, Prague, Czech Republic (2009)

5. G. Kocaslan International Journal of Energy Economics, 4, 4 (2014)

6. H. Cabalu, C. Alfonso, A.Dorsman et al. (eds.), Energy Economics and Financial Markets (Berlin, Heidelberg 2013)

7. Lefèvre N., Energy Policy (2009)

8. B. Kruyt, D.P. van Vuuren, H.J.M. de Vries, H. Groenenberg, Energy Policy, 37, 6 (2009)

9. J.C Bollen, MNP, Bilthoven (2008)

10. S.M. Senderov Safety of objects of the fuel and energy complex, 1,1 (2012)

11. Statistical form of Rosstat Information on balances, receipt and consumption of fuel and heat, collection and use of used oil products (2011-2016)

12. Statistical form of Rosstat Information on the use of fuel and energy resources (2011-2016)

13. Statistical form of Rosstat Technical and economic indicators of power plants, district boilers (2011-2016) 